\title{
Cytotoxic Cordiaquinones from the Roots of Cordia polycephala
}

\author{
Hozana Patrícia S. Freitas, ${ }^{a}$ Ana Isabel V. Maia ${ }^{a}$ Edilberto R. Silveira, ${ }^{a}$ \\ José Delano B. Marinho Filho, ${ }^{b}$ Manoel O. Moraes, ${ }^{b}$ Cláudia Pessoa, ${ }^{b}$ \\ Letícia V. Costa Lotufo ${ }^{b}$ and Otília Deusdênia L. Pessoa*,a
}

\author{
${ }^{a}$ Departamento de Química Orgânica e Inorgânica, Universidade Federal do Ceará, \\ CP 12.200, 60021-940 Fortaleza-CE, Brazil \\ ${ }^{b}$ Departamento de Farmacologia e Fisiologia, Universidade Federal do Ceará, \\ CP 3157, 60430-270 Fortaleza-CE, Brazil
}

\begin{abstract}
A investigação química das raízes de Cordia polycephala resultou no isolamento de duas novas naftoquinonas terpenoídicas, 6-[10-(12,12-dimetil-13 $\alpha$-(22-metil-21-butenoilóxi)16-metenilciclohexil)etil]-naftaleno-1,4-diona e (6-[10-(12,12-dimetil-13 $\alpha$-(tigloilóxi)-16metenilciclohexil)etil]-naftaleno-1,4-diona, designadas de cordiaquinonas $\mathrm{N}$ (1) e O (2), respectivamente. As cordiaquinonas já conhecidas, B (3), L (4) e E (5), foram também isoladas. Suas estruturas foram elucidadas após detalhada análise dos dados de $\mathrm{RMN}{ }^{1} \mathrm{H} \mathrm{e}{ }^{13} \mathrm{C}$ (1D e 2D) e EMAR (espectrometria de massas de alta resolução). Todas as cordiaquinonas (1-5) foram avaliadas contra quatro linhagens de células cancerígenas: HCT-8 (colo), HL-60 (leucemia), MDA-MB-435 (melanoma) e SF295 (glioblastoma), mostrando $\mathrm{IC}_{50}$ na faixa de 1,2 a 11,1 $\mu \mathrm{mol} \mathrm{L}^{-1}$. As novas cordiaquinonas $\mathbf{1}$ e $\mathbf{2}$ foram as mais ativas contra todas as linhagens de câncer, enquanto $\mathbf{3}$ foi mais seletiva para células leucêmicas $\left(\mathrm{IC}_{50} 2,2 \mu \mathrm{mol} \mathrm{L}{ }^{-1}\right)$.
\end{abstract}

The chemical investigation of roots of Cordia polycephala resulted in the isolation of two new terpenoid naphtoquinones, 6-[10-(12,12-dimethyl-13 $\alpha$-(22-methyl-21-butenoyloxy)-16methenylcyclohexyl)ethyl]-naphtalene-1,4-dione and (6-[10-(12,12-dimethyl-13 $\alpha$-(tigloyloxy)16-methenylcyclohexyl)ethyl]-naphtalene-1,4-dione, named as cordiaquinone $\mathrm{N}(\mathbf{1})$ and $\mathrm{O}(\mathbf{2})$, respectively. The known cordiaquinones B (3), L (4) and E (5) were also isolated. Their structures were elucidated after detailed $1 \mathrm{D}$ and 2D NMR and high resolution electrospray ionization mass spectrometry (HRESIMS) data analysis. All cordiaquinones (1-5) were evaluated against four human cancer cell lines: HCT-8 (colon), HL-60 (leukemia), MDA-MB-435 (melanoma) and SF295 (glioblastoma), showing $\mathrm{IC}_{50}$ values in the range of 1.2 to $11.1 \mu \mathrm{mol} \mathrm{L}^{-1}$. The new cordiaquinones $\mathbf{1}$ and $\mathbf{2}$ were the most active against all cancer cell lines, while compound $\mathbf{3}$ was selective to leukemia HL-60 cells ( $\left.\mathrm{IC}_{50} 2.2 \mu \mathrm{mol} \mathrm{L}{ }^{-1}\right)$.

Keywords: Cordia polycephala, cordiaquinones, cytotoxic activity

\section{Introduction}

The genus Cordia, one of the major and most important of the Boraginaceae family, is known as a prolific source of structurally diverse secondary metabolites such as sesquiterpenes, ${ }^{1}$ diterpenes,${ }^{2}$ triterpenes, ${ }^{3}$ triterpene saponins, ${ }^{4}$ and their ability to biosynthesize meroterpenoid benzoquinones and naphthoquinones, including their respective reduced forms (hydroquinones). ${ }^{5-10}$ These quinoid compounds, known as cordiaquinones, could be

*e-mail: opessoa@ufc.br considered as chemotaxinomical markers for the Cordia genus. Nevertheless, the occurrence in their producing plants is limited to the roots and rarely to the trunk wood. As part of a search for bioactive compounds from Cordia, the chemical composition of several Cordia species native to the Brazilian flora, including its pharmacological and biological effects have been performed. ${ }^{11,12}$ Previous investigations have demonstrated that cordiaquinones display anticancer activity, inducing reactive oxygen species generation and apoptosis in cancer cells. ${ }^{13,14}$ The present work describes the phytochemical analysis of the hexane extract from roots of $C$. polycephala (Lam.) I. M. 
Johnston (syn.: Cordia ulmifolia Juss, Cordia wickstroemii Steudel, Varronia polycephala Lam. Varronia paniculata Wakström), a flowering and aromatic shrub native to Brazil, Colombia, French Guiana and Suriname. In addition, the cytotoxic effect of all isolated compounds was also evaluated against four cancer cell lines.

\section{Results and Discussion}

Compound 1 was isolated as a yellow resin. Its molecular formula $\left(\mathrm{C}_{26} \mathrm{H}_{30} \mathrm{O}_{4}\right)$ was established by HRESIMS (observed $m / z$ 407.2252 $[\mathrm{M}+\mathrm{H}]^{+}$; calc. for $\mathrm{C}_{26} \mathrm{H}_{31} \mathrm{O}_{4}$ 407.2222) and NMR spectral analysis. The IR spectrum exhibited absorption bands for carbon-oxygen (1712 and $1666 \mathrm{~cm}^{-1}$ ) and carbon-carbon $\left(1600 \mathrm{~cm}^{-1}\right)$ double bonds. The ${ }^{13} \mathrm{C} \mathrm{NMR}$ spectrum displayed 26 carbon signals, identified through DEPT and HSQC experiments as eight methines (six $\mathrm{sp}^{2}$ and two $\mathrm{sp}^{3}$ ), one methylidene, four methylenes, four methyls and nine non-hydrogenated carbons (eight $\mathrm{sp}^{2}$ and one $\mathrm{sp}^{3}$ ). The ${ }^{1} \mathrm{H}$ and ${ }^{13} \mathrm{C}$ NMR features of $\mathbf{1}$ (Table 1) suggested that this compound was a 1,4-naphthoquinone, especially due to the presence of the signals at $\delta 185.6$ and 185.1. ${ }^{8,12}$ Comparison of the ${ }^{1} \mathrm{H}$ and ${ }^{13} \mathrm{C}$ NMR data of $\mathbf{1}$ with those reported for cordiaquinone $\mathrm{L},{ }^{8}$ showed high similarity, except for the presence of the additional signals at $\delta 166.4,156.9, \delta 116.5 / 5.65(\mathrm{br} \mathrm{s}), \delta 27.6 / 1.89$ (s) and $\delta 20.4 / 2.17$ (s) in $\mathbf{1}$, which were assigned to a 3-methyl2-butenoyl moiety. The position of this group at C-13 was established by the HMBC correlation exhibited between H-13 $(\delta$ 4.70) and C-20 ( $\delta$ 166.4) (Figure 1), while its equatorial position was deduced from the multiplicity and coupling constant values displayed by $\mathrm{H}-13$ (dd, $J 8.5$ and 4.5 Hz). The relative stereochemistry of $\mathbf{1}$ was established by analysis of the NOESY spectrum, which showed NOE correlations among the axial protons $\mathrm{H}-13, \mathrm{H}-11$ and Me-18 (Figure 1). Thus, the structure of $\mathbf{1}$ was established as the 6-[10-(12,12-dimethyl-13 $\alpha$-(22-methyl-21-butenoyloxy)16-methenylcyclohexyl)ethyl]-naphtalene-1,4-dione). Terpenoid naphthoquinones have been previously isolated from Cordia species and designated as cordiaquinones, an allusion to the genus. Since cordiaquinones A-M were already reported, ${ }^{8}$ compound $\mathbf{1}$ was designated as cordiaquinone $\mathrm{N}$.

Compound 2 was also obtained as a yellow resin. The molecular formula $\left(\mathrm{C}_{26} \mathrm{H}_{30} \mathrm{O}_{4}\right)$ determined by HRESIMS (observed $\mathrm{m} / \mathrm{z} 407.2206[\mathrm{M}+\mathrm{H}]^{+}$; calc. for $\mathrm{C}_{26} \mathrm{H}_{31} \mathrm{O}_{4}$, 407.2222), was identical to that of $\mathbf{1}$. Its IR spectrum exhibited absorption bands for carbon-oxygen (1703 and $\left.1667 \mathrm{~cm}^{-1}\right)$ and carbon-carbon $\left(1600 \mathrm{~cm}^{-1}\right)$ double bonds. Comparative analyses of the ${ }^{1} \mathrm{H}$ and ${ }^{13} \mathrm{C}$ NMR data of 2 with those of $\mathbf{1}$ (Table 1) showed very close structural similarity,
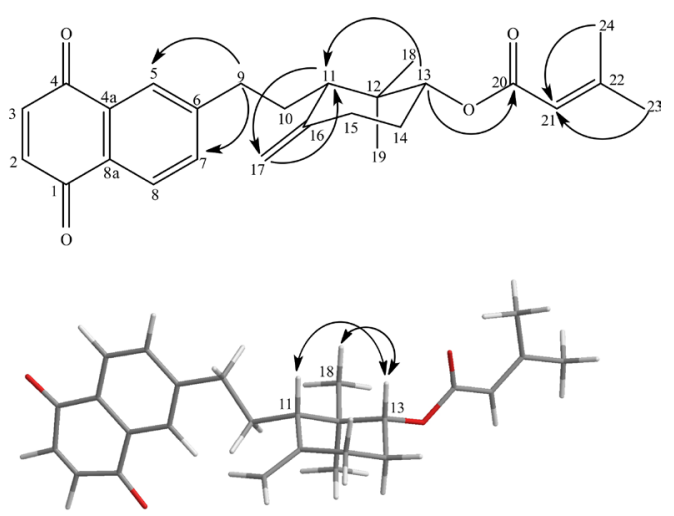

Figure 1. Relevant HMBC $(\mathrm{H} \rightarrow \mathrm{C})$ and NOESY correlations for $\mathbf{1}$.

except for the signals related to the ester side chain (C-21 to C-24). Besides the doublet at $\delta 1.76(\mathrm{~d}, J 7.0 \mathrm{~Hz})$ for a vinyl methyl (C-23) and the correspondent vinyl hydrogen at $\delta 6.81(\mathrm{q}, J 7.0 \mathrm{~Hz})$, the HMBC spectra displayed the long range correlations of the methyl protons at $\delta 1.81$ (s, H3-24) with the carbons at $\delta 167.8$ (C-20), 129.1 (C-21) and 137.2 (C-22) (Figure 2), revealing that the ester side chain was indeed a tigloyloxy moiety. The aforementioned data allowed to establish the structure of $\mathbf{2}$ as the 6-[10-(12, 12-dimethyl-13 $\alpha$-(tigloyloxy)-16-methenylcyclohexyl) ethyl]-naphtalene-1,4-dione, named cordiaquinone O. In addition to new cordiaquinones $\mathrm{N}$ and $\mathrm{O}(\mathbf{1 - 2})$, three known cordiaquinones, B (3), L (4), E (5) ${ }^{8,10}$ were isolated (Figure 3).

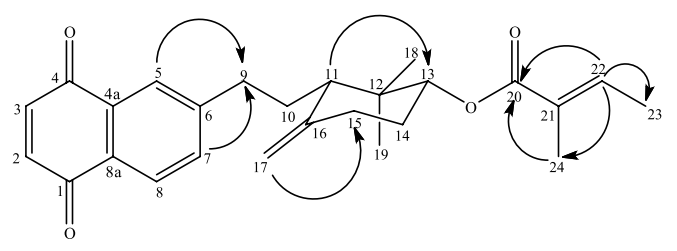

Figure 2. Relevant HMBC $(\mathrm{H} \rightarrow \mathrm{C})$ correlations for 2.

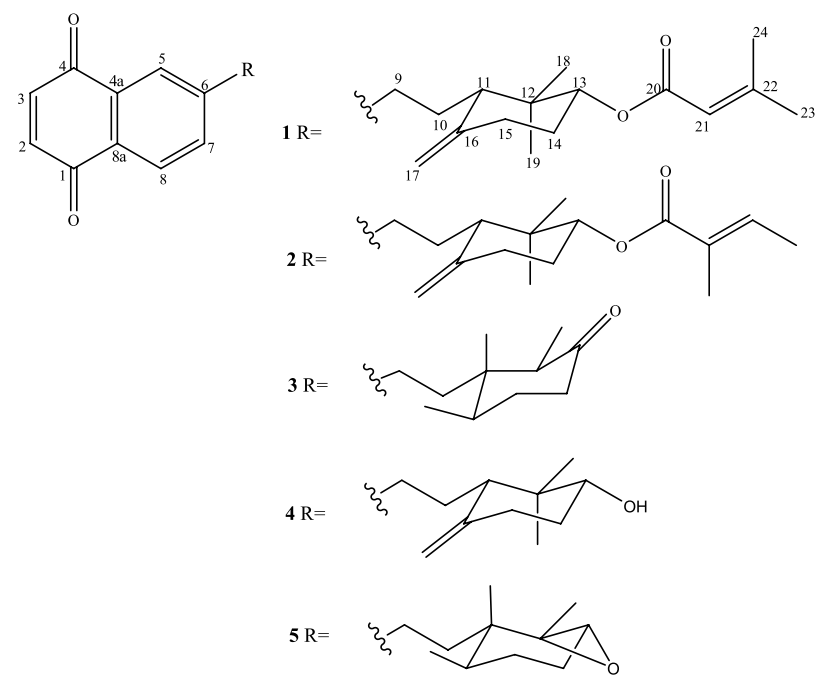

Figure 3. Structures of cordiaquinones N (1), O (2), B (3), L (4), and E (5) isolated from roots of Cordia polycephala. 
Table 1. ${ }^{1} \mathrm{H}(500 \mathrm{MHz})$ and ${ }^{13} \mathrm{C}(125 \mathrm{MHz})$ NMR data of cordiaquinones $\mathbf{1}$ and $\mathbf{2}$ in $\mathrm{CDCl}_{3}$

\begin{tabular}{|c|c|c|c|c|}
\hline \multirow{2}{*}{$\mathrm{N}$. } & \multicolumn{2}{|c|}{1} & \multicolumn{2}{|c|}{2} \\
\hline & ${ }^{13} \mathrm{C}$ & ${ }^{1} \mathrm{H}(\mathrm{J}$ in $\mathrm{Hz})$ & ${ }^{13} \mathrm{C}$ & ${ }^{1} \mathrm{H}(\mathrm{J}$ in $\mathrm{Hz})$ \\
\hline 1 & 185.1 & - & 185.1 & - \\
\hline 2 & 138.7 & $6.96, \mathrm{~s}$ & 138.7 & $6.96, \mathrm{~s}$ \\
\hline 3 & 138.9 & $6.96, \mathrm{~s}$ & 138.9 & $6.96, \mathrm{~s}$ \\
\hline 4 & 185.6 & - & 185.6 & - \\
\hline $4 a$ & 130.2 & - & 130.2 & - \\
\hline 5 & 126.3 & $7.89, \mathrm{~s}$ & 126.2 & $7.92, \mathrm{~s}$ \\
\hline 6 & 150.3 & - & 150,3 & - \\
\hline 7 & 134.3 & $7.56, \mathrm{~d}(8.0)$ & 134.2 & 7.56, d (7.9) \\
\hline 8 & 126.9 & 8.01, d (8.0) & 126.9 & 8.01, d (7.9) \\
\hline $8 \mathrm{a}$ & 132.1 & - & 132.2 & - \\
\hline 9 & 35.2 & $2.56, \mathrm{~m} ; 2.88, \mathrm{~m}$ & 35.2 & $2.54, \mathrm{~m} ; 2.87, \mathrm{~m}$ \\
\hline 10 & 27.6 & $1.92, \mathrm{~m}$ & 28.1 & $1.92, \mathrm{~m}$ \\
\hline 11 & 52.0 & 1.78, br d (13.2) & 52.2 & 1.84 , br s \\
\hline 12 & 39.4 & - & 39.4 & - \\
\hline 13 & 77.1 & $4.70, \mathrm{dd}(4.5 ; 8.5)$ & 78.1 & 4.73, br s \\
\hline 14 & 28.8 & $1.62, \mathrm{~m} ; 1.92, \mathrm{~m}$ & 28.7 & $1.68, \mathrm{~m} ; 1.92, \mathrm{~m}$ \\
\hline 15 & 31.0 & $2.06, \mathrm{~m} ; 2.36, \mathrm{~m}$ & 30.4 & $2.08, \mathrm{~m} ; 2.36, \mathrm{~m}$ \\
\hline 16 & 146.8 & - & 146.8 & - \\
\hline 17 & 110.0 & 4.71, br s; 4.98, br s & 110.3 & 4.73 , br s; 4.98, br s \\
\hline 18 & 26.5 & $0.95, \mathrm{~s}$ & 26.8 & $0.96, \mathrm{~s}$ \\
\hline 19 & 19.0 & $0.82, \mathrm{~s}$ & 19.5 & $0.86, \mathrm{~s}$ \\
\hline 20 & 166.4 & - & 167.8 & - \\
\hline 21 & 116.5 & 5.65 , br s & 129.1 & - \\
\hline 22 & 156.9 & - & 137.2 & $6.81, \mathrm{q}(7.0)$ \\
\hline 23 & 27.6 & $1.89, \mathrm{~s}$ & 14.6 & $1.76, \mathrm{~d}(7.0)$ \\
\hline 24 & 20.4 & $2.17, \mathrm{~s}$ & 12.4 & $1.81, \mathrm{~s}$ \\
\hline
\end{tabular}

The MTT analysis showed that all compounds (1-5) exhibited cytotoxic activity against tested cancer cell lines (Table 2). Compounds $\mathbf{1}$ and $\mathbf{2}$ were the most active among all, with $\mathrm{IC}_{50}$ values ranging from 1.2 to $3.4 \mu \mathrm{mol} \mathrm{L} \mathrm{L}^{-1}$, whereas for the known cordiaquinones $\mathrm{B}, \mathrm{E}$ and $\mathrm{L}, \mathrm{IC}_{50}$ ranged from 2.2 to over $15 \mu \mathrm{mol} \mathrm{L} \mathrm{L}^{-1}$. It's worthwhile to mention that cordiaquinone $\mathrm{E}$ (3) was selective towards leukemia cells $\left(\mathrm{IC}_{50} 2.2 \mu \mathrm{mol} \mathrm{L} \mathrm{L}^{-1}\right)$, since it displayed a weak activity to cells from different histological origins $\left(\mathrm{IC}_{50}>15 \mu \mathrm{mol} \mathrm{L}{ }^{-1}\right.$ in MDA-MB-435 and SF-295 cells, and $\mathrm{IC}_{50}$ of $11.1 \mu \mathrm{mol} \mathrm{L}-1$ in HCT-8 cells). None of the tested compounds (1-5) showed hemolytic activity in mice erythrocytes $\left(\mathrm{EC}_{50}>500 \mu \mathrm{mol} \mathrm{L} \mathrm{L}^{-1}\right)$, suggesting that the cytotoxicity of cordiaquinones is not related to non-specific membrane damage (Table 2). Among cordiaquinones, one could speculate about the higher activity of compounds $\mathbf{1}$ and $\mathbf{2}$ referring to the presence of the extra $\alpha$ - $\beta$-conjugated carbonyl of the end tigloyloxy side chains.

Several molecules possessing a quinone moiety show antiproliferative effects on tumor cell growth. ${ }^{15}$ The cytotoxic activity of quinones is related to inhibition of electron transporters, ${ }^{16}$ uncouple of oxidative phosphorylation, ${ }^{17} \mathrm{ROS}$ generation, ${ }^{18}$ protein adducts formation, ${ }^{19}$ especially with enzyme SH groups and DNA damage. ${ }^{15}$ In a previous work,

Table 2. Cytotoxic activity of compounds 1-5

\begin{tabular}{|c|c|c|c|c|c|}
\hline \multirow{2}{*}{ Compounds } & \multicolumn{4}{|c|}{$\mathrm{IC}_{50} /(\mu \mathrm{mol} \mathrm{L}-1)(95 \%$ confidence interval $)$} & \multirow{2}{*}{$\begin{array}{c}\text { Hemolysis } \\
\mathrm{EC}_{50} /\left(\mu \mathrm{mol} \mathrm{L}{ }^{-1}\right)\end{array}$} \\
\hline & HL-60 & HCT-8 & SF-295 & MDA-MB-435 & \\
\hline 1 & $1.5(1.0-2.0)$ & $2.3(1.5-3.7)$ & $1.8(1.5-2.2)$ & $2.9(2.4-3.7)$ & $>500$ \\
\hline 2 & $1.2(0.7-2.0)$ & $1.2(1.0-1.5)$ & $2.0(1.7-2.4)$ & $3.4(2.9-3.9)$ & $>500$ \\
\hline 3 & $2.2(0.9-4.3)$ & $11.1(10.5-12.0)$ & $>15$ & $>15$ & $>500$ \\
\hline 4 & $5.0(4.2-5.8)$ & $5.0(4.3-5.8)$ & $4.6(4.0-5.2)$ & $7.5(6.5-8.6)$ & $>500$ \\
\hline 5 & $8.8(6.5-9.3)$ & $9.3(7.5-11.0)$ & $10.8(6.3-12.0)$ & $9.6(7.1-13.0)$ & $>500$ \\
\hline Doxorubicin & $0.03(0.02-0.05)$ & $0.02(0.02-0.03)$ & $0.4(0.3-0.6)$ & $0.8(0.6-1.1)$ & $\mathrm{Nd}$ \\
\hline
\end{tabular}


it was described for the first time the mechanisms underlying the cytotoxic effects of cordiaquinones. Cordiaquinone J, isolated from $C$. leucocephala, demonstrated a rapid induction of apoptosis and necrosis in a mechanism dependent of the generation of reactive oxygen species in leukemia cells. ${ }^{14}$

\section{Experimental}

\section{General experimental procedures}

Optical rotations were measured on a Perkin-Elmer 341 digital polarimeter. IR (4000 to $650 \mathrm{~cm}^{-1}$ ) spectra were obtained on a Perkin-Elmer 100 FT-IR spectrum. The high resolution electrospray ionization mass spectra (HRESIMS) were acquired using a LCMS-IT-TOF (SHIMADZU) spectrometer. ${ }^{1} \mathrm{H}(500 \mathrm{MHz})$ and ${ }^{13} \mathrm{C}$ NMR $(125 \mathrm{MHz})$ spectra were performed on a Bruker DRX-500 spectrometer. HPLC analysis was carried out using a UFLC (SHIMADZU) system equipped with a SPD-M20A diode array UV-Vis detector and a Phenomenex LC-Silica column, $5 \mu \mathrm{m}(4.6 \times 250 \mathrm{~mm})$. The mobile phase was consisted of hexane $/ \mathrm{CHCl}_{3}(65: 35 \mathrm{v} / \mathrm{v})$ with a $4.72 \mathrm{~mL} \mathrm{~min}^{-1}$ flow rate, and the chromatograms were acquired at $247 \mathrm{~nm}$. Column chromatography was carried out on silica gel 60 (70-230 mesh, Vetec or 230-400 mesh, Merck), TLC was performed on precoated silica gel aluminium sheets (kieselgel $60 \mathrm{~F}_{254}, 0.20 \mathrm{~mm}$, Merck). Fractions and pure compounds were monitored by TLC, and the spots were visualized by the color reaction by spraying with a solution of vanillin/perchloric acid/EtOH followed by heating (ca. $100^{\circ} \mathrm{C}$ ).

\section{Plant material}

Roots of Cordia polycephala were collected in August 2009 along the road margins at Pico-Alto, GuaramirangaCE, Brazil, and identified by Maria Iracema B. Loiola, botanist of the Federal University of Ceará, Brazil. The voucher specimen (IAC \# 44.582) has been deposited at the Herbário Prisco Bezerra, at the Departamento de Biologia of the Universidade Federal do Ceará, Brazil.

\section{Extraction and isolation}

Roots of C. polycephala $(2.0 \mathrm{Kg})$, dried and pulverized, were extracted with hexane at room temperature. The solvent was removed under reduced pressure to yield a dark extract (20 g), which was fractioned over silica gel by elution with hexane, hexane/EtOAc (9:1, 8:2, 6:4, 4:6, 2:8), EtOAc and $\mathrm{MeOH}$ to yield 63 fractions $(30 \mathrm{~mL}$ each), which after TLC analysis were combined into eight fractions (F1-F8). F4 (6.9 g, obtained by elution with hexane/EtOAc 6:4) was subjected to repeated column chromatography using hexane/EtOAc mixtures as eluents. The sub-fraction hexane/EtOAc 9:1 (250 mg) was applied to HPLC separation using a Gemini Phenomenex LC-Silica column (250 $\mathrm{mm} \times 4.6 \mathrm{~mm}$ i.d.) in the isocratic mode (hexane/ $\mathrm{CHCl}_{3} 65: 35, \mathrm{v} / \mathrm{v}$ ) at a flow rate of $4.72 \mathrm{~mL} \mathrm{~min}^{-1}$, with an injection volume ('loop') of $200 \mu \mathrm{L}$, to yield compounds 1 (7.5 mg) and 2 (11.0 mg). F5 (4.8 g, obtained with hexane/EtOAc 4:6) was fractioned over silica gel eluting with hexane/EtOAc (9:1, 8:2, 6:4, 4:6, 2:8) and EtOAc. From the hexane/EtOAc 9:1 fraction $(523.4 \mathrm{mg}$ ), the cordiaquinone $\mathrm{E}(\mathbf{3}, 39.2 \mathrm{mg})$ was isolated. The subfraction hexane/EtOAc 6:4 (2.2 g) was subjected to silica gel column chromatography using the same solvent system. From the hexane/EtOAc 8:2 the cordiaquinone B (4, $133.6 \mathrm{mg}$ ) was obtained. The fraction obtained with hexane/ EtOAc 6:4 (135 mg) was submitted to semipreparative HPLC using the same column and the isocratic mode, as above, but using hexane/isopropanol (95:05, v/v) at a flow rate of $4.0 \mathrm{~mL} \mathrm{~min}^{-1}$, with an injection volume ('loop') of $200 \mu \mathrm{L}$, to yield cordiaquinone L (5, $28.4 \mathrm{mg}$ ).

\section{Cell lines and cells culture}

The human cell lines used in this work were HL-60 (promyelocytic leukemia), HCT-8 (colon), MDA-MB-435 (melanoma) and SF-295 (brain), which were all obtained from the National Cancer Institute (Bethesda, MD, USA). The cells were maintained in RPMI 1640 medium supplemented with $10 \%$ fetal bovine serum, $2 \mathrm{mmol} \mathrm{L}^{-1}$ glutamine, $100 \mathrm{U} \mathrm{mL}^{-1}$ penicillin, and $100 \mu \mathrm{g} \mathrm{mL}^{-1}$ streptomycin at $37^{\circ} \mathrm{C}$ with $5 \% \mathrm{CO}_{2}$.

Inhibition of cancer cells proliferation

The cytotoxicity of all cordiaquinones were tested against the HL-60 (promyelocytic leukemia), HCT-8 (colon), MDA-MB-435 (melanoma) and SF-295 (brain) cell lines. For all experiments, cells were plated in 96-well plates $\left(10^{5}\right.$ cells per well for adherent cells or $0.3 \times 10^{5}$ cells $p e r$ well for suspended cells in $100 \mu \mathrm{L}$ of medium). After $24 \mathrm{~h}$, all cordiaquinones (0.06-77.0 $\left.\mu \mathrm{mol} \mathrm{L}^{-1}\right)$ dissolved in $1 \% \mathrm{DMSO}$ were added to each well using a high throughput screening system (Biomek 3000-Beckman Coulter, Inc. Fullerton, CA, USA), and the cultures were incubated for $72 \mathrm{~h}$. Doxorubicin (Zodiac) was used as a positive control. Control groups received the same amount of DMSO. Tumor cell growth was quantified by the ability of living cells to reduce the yellow dye 3-(4,5-dimethyl-2-thiazolyl)-2,5-diphenyl-2H- 
tetrazoliumbromide (MTT) to a purple formazan product. ${ }^{20}$ At the end of the incubation, the plates were centrifuged and the medium was replaced with fresh medium $(150 \mu \mathrm{L})$ containing MTT $\left(0.5 \mathrm{mg} \mathrm{mL}^{-1}\right)$. Three hours later, the plates were centrifuged, the MTT formazan product was dissolved in $150 \mu \mathrm{L} \mathrm{DMSO}$, and the absorbance was measured using a multiplate reader (Spectra Count, Packard, Ontario, Canada). The drug effect was quantified as the percentage of the control absorbance of the reduced dye at $595 \mathrm{~nm}$.

Hemolytic activity

Membrane disruption was performed in 96-well plates. Briefly, each well received $100 \mu \mathrm{L}$ of a $0.85 \% \mathrm{NaCl}$ solution containing $10 \mathrm{mmol} \mathrm{L}^{-1} \mathrm{CaCl}_{2}$ and $100 \mu \mathrm{L}$ of a $2 \%$ suspension of mouse erythrocytes in the same medium. The cordiaquinones were tested at concentrations ranging from 12 to $500 \mu \mathrm{mol} \mathrm{L}^{-1}$. Triton X-100 (Isofar, Brazil) at $0.1 \%$ (in $0.85 \% \mathrm{NaCl}$ ) was used as a positive control. After incubation for $60 \mathrm{~min}$ at room temperature, the plate was centrifuged, the supernatant was removed and the liberated hemoglobin was measured at $540 \mathrm{~nm}$ (DTX-880, Beckman Coulter $\left.{ }^{\circledR}\right) .{ }^{21}$

\section{Conclusions}

From roots of $C$. polycephala were isolated five terpenoid naphtoquinones, two of which are new. The isolation of additional new terpenoid quinones from Cordia species reinforces the importance of this type of compounds as possible chemomarkers for the genus. All naphthoquinones showed antiproliferative effects, particularly the new compounds ( $\mathbf{1}$ and $\mathbf{2})$. The investigation of plants from Cordia species as a source of anticancer agents could improve the development of new drugs.

\section{Supplementary Information}

Supplementary information for compounds $\mathbf{1}$ and $\mathbf{2}$ is available free of charge at http://jbcs.sbq.org.br as PDF file.

\section{Acknowledgments}

This work was supported by grants from the Brazilian Governmental Agencies: CAPES, CNPq, PRONEX, FUNCAP and INCT.

\section{References}

1. Menezes, J. E. S.; Machado, A. F. E. A.; Lemos, T. L. G.; Silveira, E. R.; Braz-Filho, R.; Pessoa, O. D. L.; Z. Naturforsch., C: Biosci. 2004, 59, 19.
2. Siddqui, B. S.; Perwaiz, S.; Begum, S.; Tetrahedron 2006, 62, 10087.

3. Kuroyanagi, M.; Kawahara, N.; Sekita, S.; Satake, M.; Hayashi, T.; J. Nat. Prod. 2003, 66, 1307.

4. Santos, R. P.; Viana, F. A.; Lemos, T. L. G.; Silveira, E. R.; Braz-Filho, R.; Pessoa, O. D. L.; Magn. Reson. Chem. 2003, 41,735 .

5. Bieber, L. W.; Messana, I.; Lins, S. C. N.; da Silva Filho, A. A.; Chiappeta, A. A.; Méllo, J. F.; Phytochemistry 1990, 29, 1955.

6. Ioset, J. R.; Marston, A.; Gupta, M. P.; Hostettmann, K.; J. Nat. Prod. 2000, 63, 424.

7. Mori, K.; Kawano, M.; Fuchino, H.; Ooi, T.; Satake, M.; Agatsuma, Y.; Kusumi, T.; Sekita, S.; J. Nat. Prod. 2008, 71, 18.

8. Diniz, J. C.; Viana, F. A.; Oliveira, O. F.; Maciel, M. A. M.; Torres, M. C. M.; Braz-Filho, R.; Silveira, E. R.; Pessoa, O. D. L.; Magn. Reson. Chem. 2009, 47, 190.

9. Dettrakul, S.; Surerum, S.; Rajviroongit, S.; Kittakoop, P.; J. Nat. Prod. 2009, 72, 861.

10. Ioset, J. R.; Marston, A.; Gupta, M. P.; Hostettmann, K.; Phytochemistry 1998, 47, 729.

11. Lemos, T. L. G.; Monte, F. J. Q.; Santos, A. K. L.; Santos, H. S.; Oliveira, M. F.; Costa, S. M.; Pessoa, O. D. L.; Braz-Filho, R.; Nat. Prod. Res. 2007, 21, 529.

12. Ioset, J. R.; Marston, A.; Gupta, M. P.; Hostettmann, K.; J. Nat. Prod. 2000, 53, 613.

13. Menezes, J. E. S. A.; Lemos, T. L. G.; Pessoa, O. D. L.; BrazFilho, R.; Montenegro, R. C.; Wilke, D. V.; Costa-Lotufo, L. V.; Pessoa, C.; De Moraes, M. O.; Silveira, E. R.; Planta Med. 2005, 71, 54

14. Marinho-Filho, J. D. B.; Bezerra, D. P.; Araújo, A. J.; Montenegro, R. C.; Pessoa, C.; Diniz, J. C.; Viana, F. A.; Pessoa, O. D. L; Silveira, E. R.; Moraes, M. O.; Costa-Lotufo, L. V.; Chem. Biol. Interact. 2010, 183, 369.

15. Asche, C.; Mini Rev. Med. Chem. 2005, 5, 449.

16. Vennerstrom, J. L.; Vennerstrom, J. W.; J. Med. Chem. 1988, 31, 1269.

17. Howland, J. L.; Biochim. Biophys. Acta 1963, 77, 419.

18. Monks, T. J.; Hanzlik, R. P.; Cohen, G. M.; Ross, D.; Graham, D. G.; Toxicol. Appl. Pharmacol. 1992, 112, 2.

19. Kleiner, H. E.; Rivera, M. I.; Pumford, N. R.; Monks, T. J.; Lau, S. S.; Chem. Res. Toxicol. 1998, 111, 282.

20. Mosmann, T.; J. Immunol. Methods 1983, 65, 55.

21. Jimenez, P. C.; Fortier, S. C.; Lotufo, T. M. C.; Pessoa, C.; Moraes, M. E. A.; Moraes, M. O. Costa-Lotufo, L. V.; J. Exp. Mar. Biol. Ecol. 2003, 287, 93.

Submitted: March 12, 2012

Published online: August 7, 2012 